\title{
Expanding the geographic and geochronologic range of early pinnipeds: New specimens of Enaliarctos from Northern California and Oregon
}

\author{
Ashley W. Poust and Robert W. Boessenecker \\ Acta Palaeontologica Polonica 63 (1), 2018: 25-40 doi:https://doi.org/10.4202/app.00399.2017
}

The early pinnipedimorph Enaliarctos was a marine-adapted carnivore with dental and locomotor features intermediate between terrestrial arctoids and living pinnipeds. New specimens of Enaliarctos are described from Oligocene and Miocene deposits on the Pacific coast of North America, and include the oldest enaliarctine mandible (Yaquina Formation, 30.6-27.4 Ma), the first enaliarctine from Northern California (Skooner Gulch Formation, 23.8-22 Ma), and the stratigraphically youngest fossil of the genus (Astoria Formation, 17.3-16.6 Ma). The wide biogeographic and temporal range of Enaliarctos provided the potential for interaction or competition with plotopterid birds, odontocete whales, and crown pinnipeds such as early odobenids, early otariids, and desmatophocids. The expansion of the known ranges of Enaliarctos species and the description of additional morphology, particularly of the mandible and lower dentition, provides insight into the origins of pinniped diversity and their possible interactions with other early Neogene coastal marine organisms.

Key words: Mammalia, Arctoidea, Pinnipedia, Enaliarctos, Miocene, Pacific.

Ashley W. Poust [ashley.poust@ berkeley.edu], Department of Integrative Biology, Berkeley, University of California Museum of Paleontology, Berkeley, California, 94720 USA. Robert W. Boessenecker [boesseneckerrw@ cofc.edu], University of California Museum of Paleontology, Berkeley, Cali fornia, 94720 USA; Department of Geology, College of Charleston, South Carolina, 29424 USA.

This is an open-access article distributed under the terms of the Creative Commons Attribution License (for details please see creativecommons.org), which permits unrestricted use, distribution, and reproduction in any medium, provided the original author and source are credited. 
Farf Full text $(1,382.6 \mathrm{kB})$ 